\title{
1 Post-Stroke Physical Activity Improves Middle Cerebral Artery Dynamic Response
}

2 Sandra A. Billinger, PT, PhD ${ }^{1,2,3,4}$; Alicen A. Whitaker, DPT ${ }^{1}$; Allegra Morton, BS ${ }^{1}$; Carolyn S.

3 Kaufman, BS ${ }^{1,4}$; Sophy J Perdomo, $\mathrm{PhD}^{1}$; Jaimie L. Ward, MS ${ }^{1}$; Sarah M. Eickmeyer, MD ${ }^{2}$;

4 Stephen X. Bai, MD²; Luke Ledbetter, MD ${ }^{5}$; Michael G. Abraham, MD ${ }^{3,6}$

$6 \quad{ }^{1}$ Department of Physical Therapy and Rehabilitation Science, University of Kansas Medical

7 Center, Kansas City, KS

$8{ }^{2}$ Department of Physical Medicine and Rehabilitation, University of Kansas Medical Center,

9 Kansas City, KS

$10{ }^{3}$ Department of Neurology, University of Kansas Medical Center, Kansas City, KS

$11{ }^{4}$ Department of Integrative and Molecular Physiology, University of Kansas Medical Center,

12 Kansas City, KS

$13{ }^{5}$ Department of Diagnostic Radiology, University of Kansas Medical Center, Kansas City, KS

$14{ }^{6}$ Department of Interventional Radiology, University of Kansas Medical Center, Kansas City, KS

16 Corresponding Author:

17 Sandra A. Billinger, PT, PhD

18 Address: 3901 Rainbow Blvd, Mail Stop 2002, Kansas City, KS 66160

19 Phone number: 913-945-6685

20 Fax: 913-588-9428

21 Email: sbillinger@kumc.edu 
medRxiv preprint doi: https://doi.org/10.1101/2020.05.13.20100883; this version posted May 16, 2020. The copyright holder for this preprint (which was not certified by peer review) is the author/funder, who has granted medRxiv a license to display the preprint in perpetuity.

It is made available under a CC-BY-NC 4.0 International license.

22 Abstract

23 Background and Purpose: The primary aim was to characterize the middle cerebral artery

24 blood velocity (MCAv) dynamic response to an acute bout of exercise at 3- and 6-months post

25 stroke. As a secondary objective, we grouped individuals according to the MCAv dynamic

26 response to the exercise bout as responder or non-responder. We tested whether physical activity,

27 aerobic fitness and exercise mean arterial blood pressure (MAP) differed between groups.

28 Methods: Transcranial Doppler ultrasound measured MCAv during a 90-second baseline (BL)

29 followed by a 6-minute moderate intensity exercise bout. Heart rate (HR), MAP and end tidal

$30 \mathrm{CO}_{2}\left(\mathrm{P}_{\mathrm{ET}} \mathrm{CO}_{2}\right)$ were additional variables of interest. The MCAv dynamic response variables

31 included: BL, time delay (TD), amplitude and time constant $(\tau)$.

32 Results: Individuals enrolled in the study at 3 months post-stroke and the follow up visit

33 commenced at 6 months post-stroke. Linear mixed model revealed no significant differences in

34 our selected outcomes across between 3- and 6-months post-stroke. Individuals characterized as

35 responders demonstrated a faster TD, higher amplitude, reported higher levels of physical

36 activity and aerobic fitness when compared to the non-responders. No between group

37 differences were identified for BL, $\tau$ or exercise MAP. In the non-responders, we observed an

38 immediate rise in MCAv following exercise onset followed by an immediate decline to near BL

39 values while the responders showed an exponential rise until steady state was reached.

40 Conclusions: The MCAv dynamic response profile has the potential to provide valuable

41 information during an acute exercise bout following stroke. Individuals with a greater MCAv

42 response to the exercise stimulus reported regular participation in exercise than those who

43 reported being sedentary. 
medRxiv preprint doi: https://doi.org/10.1101/2020.05.13.20100883; this version posted May 16, 2020. The copyright holder for this preprint (which was not certified by peer review) is the author/funder, who has granted medRxiv a license to display the preprint in perpetuity.

It is made available under a CC-BY-NC 4.0 International license .

\section{$44 \quad$ Introduction}

45 Impaired cerebrovascular hemodynamic response during exercise has been reported in

46 individuals within one year post-stroke. ${ }^{1}$ We previously demonstrated individuals with middle

47 cerebral artery (MCA) stroke showed no significant differences in resting MCA blood velocity

48 (MCAv) when compared to age- and sex-matched peers. ${ }^{2}$ However, the MCAv dynamic

49 response during exercise was significantly lower for those post-stroke. Despite the impaired

50 cerebrovascular response to exercise, a six-month aerobic exercise treadmill training program in

51 chronic stroke survivors conferred benefit on cerebrovascular reserve for those randomized to the

52 intervention when compared to controls. ${ }^{3}$ This evidence, albeit limited, suggests potential

53 impairment in cerebrovascular control mechanisms following stroke.

55 The primary objective of this study was to characterize the MCAv dynamic response to a

56 moderate intensity acute exercise bout at 3-and 6-months post stroke. We hypothesized that the

57 dynamic response profile would improve from 3- to 6-months post-stroke. In our previous work

58 comparing young and older adults, we excluded one older female participant from analysis as her

59 data did not fit the exponential model. ${ }^{4}$ Rather than exclude participants with stroke whose data

60 may not fit the exponential model, we decided further scientific inquiry was warranted. As a

61 secondary objective, we divided participants into responders and non-responders based on the

62 model fit. We compared physical activity levels and hemodynamic exercise response. We

63 hypothesized that individuals in the responder group would report greater physical activity,

64 higher estimated $V \square \mathrm{O}_{2}$ maximum and higher mean arterial blood pressure (MAP) during

65 exercise when compared to non-responders. 
medRxiv preprint doi: https://doi.org/10.1101/2020.05.13.20100883; this version posted May 16, 2020. The copyright holder for this preprint (which was not certified by peer review) is the author/funder, who has granted medRxiv a license to display the preprint in perpetuity.

It is made available under a CC-BY-NC 4.0 International license .

\section{Methods}

Participants

69 We identified individuals post-stroke during the acute or inpatient rehabilitation stay at the

70 University of Kansas Health System. Inclusion criteria were: 1) unilateral ischemic stroke, 2)

71 stenosis in the common and internal carotid artery was $<70 \%{ }^{3,5}$ A radiologist (LL) made this

72 interpretation using ultrasound imaging or angiogram in the electronic medical record, 3) 35-95

73 years of age, 4) physician approval for exercise participation, 5) able to walk >10 meters without

74 physical assistance and 6) able to travel to the university for the experimental protocol.

75 Exclusion criteria were: 1) unable to consent, 2) inability to perform the exercise movements on

76 the seated recumbent stepper (T5XR NuStep, Inc. Ann Arbor, MI), 3) diagnosis of other

77 neurologic disease, and 4) use of supplemental oxygen.

\section{Experimental Procedure}

80 Study visits occurred in a laboratory setting at 3- and 6-months post-stroke. Participants were

81 asked to abstain from caffeine for a minimum of six hours, a meal for two hours, and vigorous

82 exercise at least twelve hours prior to the study visit. ${ }^{4,6}$ The University of Kansas Medical Center

83 Human Subjects Committee approved all experimental procedures. Institutionally approved

84 written informed consent was obtained from each individual prior to study participation.

\section{Familiarization}

87 The laboratory room in which the experimental protocol took place was dimly lit, quiet and

88 maintained a constant temperature between $22-24^{\circ} \mathrm{C} .{ }^{6}$ All external stimuli were kept to a minimum. 
medRxiv preprint doi: https://doi.org/10.1101/2020.05.13.20100883; this version posted May 16, 2020. The copyright holder for this preprint (which was not certified by peer review) is the author/funder, who has granted medRxiv a license to display the preprint in perpetuity.

It is made available under a CC-BY-NC 4.0 International license .

89 Participants completed the familiarization session as previously described. ${ }^{2,4,6}$ Following familiarization, we obtained height, weight and completed remaining study documents.

Protocol Set Up

93 Individuals were instrumented with the following equipment: 1) transcranial Doppler ultrasound

94 (TCD) (Multigon Industries Inc. Yonkers, NY) and 2-MHz TCD probes for acquisition of

95 MCAv $\left(\mathrm{cm}^{*} \mathrm{sec}^{-1}\right)$. The TCD sonographer was blinded to the side of stroke; 2) A 5- lead

96 electrocardiogram (ECG) (Cardiocard, Nasiff Associates, Central Square, NY) recorded HR; 3)

97 beat to beat MAP was obtained from the left middle finger (Finometer, Finapres Medical

98 Systems, Amsterdam, The Netherlands); and 4) nasal cannula and capnograph (BCI Capnocheck

99 Sleep 9004 Smiths Medical, Dublin, $\mathrm{OH})$ assessed end-tidal carbon dioxide $\left(\mathrm{P}_{\mathrm{ET}} \mathrm{CO}_{2}\right)$. We

100 monitored $\mathrm{P}_{\mathrm{ET}} \mathrm{CO}_{2}$ to ensure participants did not hyperventilate. Raw data acquisition occurred

101 through an analog-to-digital unit (NI-USB-6212, National Instruments) and custom written

102 software operating in MATLAB (v2014a, The Mathworks Inc. Natick, MA).

\section{Exercise Protocol}

105 We used moderate intensity exercise (45\% to 55\% of the participant's heart rate reserve) for the

106 acute exercise bout. We determined the HR range from one of two equations: 1) age-predicted

107 (220- age) HR maximum $\left(\mathrm{HR}_{\max }\right)$ or 2) 164- $0.72 \mathrm{x}$ age for participants using beta-blocker

108 medication. $^{7}$

The baseline (BL) recording lasted 90 seconds followed by 6 minutes of moderate intensity

111 exercise. Following the 6-minute exercise bout, the participant engaged in an active cool down 
medRxiv preprint doi: https://doi.org/10.1101/2020.05.13.20100883; this version posted May 16, 2020. The copyright holder for this preprint (which was not certified by peer review) is the author/funder, who has granted medRxiv a license to display the preprint in perpetuity.

It is made available under a CC-BY-NC 4.0 International license.

112 for 2 minutes followed by rest until HR, MCAv and MAP returned to BL values. Participants

113 performed a second exercise bout and data points were averaged to optimize signal to noise

114 ratio. $^{6}$ All variables were sampled at $500 \mathrm{~Hz}$ and then interpolated to $2.0 \mathrm{~Hz}$. Three-second

115 averages were calculated and then smoothed using a 9-second sliding window average. We used

$116 \mathrm{R}$ version 3.2.4 (R Core team, Vienna, Austria) ${ }^{8}$ with the 'nls' function package to model the

117 response. To ensure data quality, data with R-to-R intervals greater than $5 \mathrm{~Hz}$ or changes in peak

118 blood velocity greater than $10 \mathrm{~cm} / \mathrm{s}$ in a single cardiac cycle were considered artifact and

119 censored. If acquisitions had more than $15 \%$ of data points censored, they were discarded.

120

121

MCAv and Dynamic Response Profile

122 Kinetics were modeled for MCAv over the entire exercise bout with a mono-exponential model:

$$
\operatorname{MCA}_{\mathrm{V}}(t)=\mathrm{BL} *(\mathrm{t}<=\mathrm{TD})+\left(\mathrm{BL}+\operatorname{Amp}\left(1-\mathrm{e}^{-(t-\mathrm{TD}) / \tau}\right) *(\mathrm{t}>\mathrm{TD})\right.
$$

124 where $\mathrm{MCA}_{\mathrm{V}}(t)$ is the $\mathrm{MCA}_{\mathrm{V}}$ at any point in time, BL is baseline before exercise onset, Amp is 125 the peak amplitude of the response above resting BL, TD is the time delay proceeding the 126 exponential increase in $\mathrm{MCA}_{V}$, and $\tau$ is the time constant or time-to-63\% of the peak amplitude.

129 Participants were given a 20-minute rest following the exercise session. HR and blood pressure 130 were taken to ensure the participant sufficiently recovered from the exercise bout. The 6MWT 131 was performed in a hallway with no distractions or foot traffic according to guidelines outlined by the American Thoracic Society. ${ }^{9}$

134 Statistical Analysis 
medRxiv preprint doi: https://doi.org/10.1101/2020.05.13.20100883; this version posted May 16, 2020. The copyright holder for this preprint (which was not certified by peer review) is the author/funder, who has granted medRxiv a license to display the preprint in perpetuity.

It is made available under a CC-BY-NC 4.0 International license.

135 Data are presented as mean \pm standard deviation. To account for the missing data across study

136 visits, we used a linear mixed model to test for differences between 3- and 6-months post stroke.

137 To test for between group differences (responders vs non-responders), we performed one-way

138 ANOVA or Mann Whitney $\mathrm{U}$ as appropriate following visual inspection of probability plots and

139 Shapiro-Wilk tests. Fisher exact tests were used for categorical data. Differences were

140 considered significant when $\mathrm{p}<0.05$.

\section{Results}

Participant Characteristics

144 We consented 27 participants into the study. One person was consented twice as this individual

145 experienced 2 separate stroke events and has been published as a case report. ${ }^{10}$ Data from the

146 second stroke was not included. Participant demographics $(n=26)$ at enrollment are presented in

147 Table 1 . No serious adverse events occurred during any study visit.

152 Reasons for loss to follow up included: unable to contact $(n=2)$; participant's son had a stroke

$153(\mathrm{n}=1)$; hospitalized $(\mathrm{n}=1)$; visit scheduled but did not attend study visit $(\mathrm{n}=2)$; no

154 transportation $(\mathrm{n}=1)$ and participant died $(\mathrm{n}=1)$. 
medRxiv preprint doi: https://doi.org/10.1101/2020.05.13.20100883; this version posted May 16, 2020. The copyright holder for this preprint (which was not certified by peer review) is the author/funder, who has granted medRxiv a license to display the preprint in perpetuity.

It is made available under a CC-BY-NC 4.0 International license .

3-Month Visit. Of the 26 participants, four individuals were excluded from analysis due to: a valid MCAv signal was not acquired, $\mathrm{n}=3$ and poor MCAv signal acquisition during exercise, $\mathrm{n}=1$. Data are presented for 22 participants.

6-Month Visit. Of the 18 individuals who returned, we excluded 3 datasets from analysis.

Reasons for exclusion included an invalid MCAv signal, $\mathrm{n}=2$ and poor MCAv signal acquisition during exercise, $\mathrm{n}=1$. Statistical analyses were conducted on 15 datasets.

The MCAv BL and kinetic measures during moderate intensity exercise showed no differences over time for the stroke affected and non-stroke affected MCAv (Table 2). We found no differences between race $(\mathrm{p}=0.09)$ or sex $(\mathrm{p}=0.21)$ for all MCAv data and hemodynamic data (blood pressure, heart rate and $\mathrm{P}_{\mathrm{ET}} \mathrm{CO}_{2}$ ) at rest and during exercise at either 3- or 6-month visits.

\section{Responders and Non-Responders (3 Months Post-stroke)}

\section{MCAv Dynamic Response}

Table 3 presents demographics for each group. We observed 12 participants whose MCAv increased in a close-to-exponential pattern being well-fit by a delay + exponential function (responders). The remaining 10 individuals (non-responders) demonstrated poor model fit with visual inspection $(n=5)$, non-exponential response $(n=4)$ or MCAv was below BL $(n=1)$ after exercise onset on the stroke affected side. On the non-stroke affected side, MCAv decreased below BL after exercise onset for the same individual $(\mathrm{n}=1)$ and we observed a non-exponential response in the other participants $(n=9)$. No between group differences were reported for age, body mass index, 6MWT or the MoCA. The responders were more likely to report taking a statin 
medRxiv preprint doi: https://doi.org/10.1101/2020.05.13.20100883; this version posted May 16, 2020. The copyright holder for this preprint (which was not certified by peer review) is the author/funder, who has granted medRxiv a license to display the preprint in perpetuity.

It is made available under a CC-BY-NC 4.0 International license.

medication, had greater physical activity levels and had higher estimated $V \sqcap \mathrm{O}_{2}$ maximum values $(\mathrm{p}<0.05)$.

Figure 1 shows the BL and MCAv response after the onset of moderate intensity exercise for responders and non-responders. Data from the MCAv kinetics analysis are presented in Table 4. During seated rest prior to exercise onset, BL data for the stroke affected and non-stroke affected MCAv were not significantly different between groups. After exercise onset, MCAv amplitude on the stroke affected side was significantly reduced in the non-responders. This finding is expected based on group assignment (responder/non-responder). For the 5 participants with poor model fit, we observed a significantly slower TD response for the non-responders on the stroke affected side while the $\tau$ was not different. Only one person in the non-responder group had data for analysis that fit the model, although a negative amplitude (below BL). The remaining participants $(n=9)$ showed a non-exponential response.

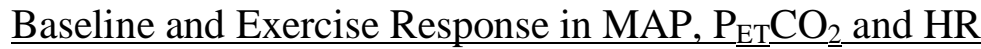

The baseline and exercise-induced responses $(\Delta)$ in MAP, $\mathrm{P}_{\mathrm{ET}} \mathrm{CO}_{2}$ and $\mathrm{HR}$ are shown in Table 4. The BL and steady state exercise for MAP, $\mathrm{P}_{\mathrm{ET}} \mathrm{CO}_{2}$ and $\mathrm{HR}$ were not significantly different. We found between group differences for $\triangle \mathrm{MAP}$ and $\Delta \mathrm{HR}(\mathrm{p}<0.025)$ but not $\Delta \mathrm{P}_{\mathrm{ET}} \mathrm{CO}_{2}(\mathrm{p}=0.22)$.

\section{Responders and Non-Responders (6 Months Post-stroke)}

All individuals characterized as a responder at the 3-month visit remained at the 6-month visit.

Three individuals initially characterized as a non-responder met the criteria for responder. Of these three individuals, two increased their physical activity score from a 2 (low intensity 
medRxiv preprint doi: https://doi.org/10.1101/2020.05.13.20100883; this version posted May 16, 2020. The copyright holder for this preprint (which was not certified by peer review) is the author/funder, who has granted medRxiv a license to display the preprint in perpetuity.

It is made available under a CC-BY-NC 4.0 International license.

$214 \quad(\mathrm{p}=0.02)$.

MCAv Dynamic Response

Responders worked at a higher workload $(\mathrm{p}=0.04)$ with no significant differences in the rate of

218 perceived exertion $(\mathrm{p}=0.96)$. BL MCAv was not different between groups for the stroke

219 affected $(\mathrm{p}=0.58)$ and non-stroke affected MCA $(\mathrm{p}=0.87)$. For the stroke affected MCA, the

220 non-responders showed a significantly slower TD $(\mathrm{p}=0.04)$ and lower amplitude $(\mathrm{p}=0.04)$

221 while $\tau$ was not different $(\mathrm{p}=0.93)$. For the non-stroke affected MCA, no between group

222 significant differences were found for any MCAv dynamic response variables.

224 Baseline and Exercise Response in MAP, $\mathrm{P}_{\mathrm{ET}} \underline{\mathrm{CO}_{2}} \underline{\text { and } \mathrm{HR}}$ 
medRxiv preprint doi: https://doi.org/10.1101/2020.05.13.20100883; this version posted May 16, 2020. The copyright holder for this preprint (which was not certified by peer review) is the author/funder, who has granted medRxiv a license to display the preprint in perpetuity.

It is made available under a CC-BY-NC 4.0 International license.

225 No between group differences were found for resting and exercise hemodynamic responses,

$226 \Delta \mathrm{MAP}, \Delta \mathrm{HR}$ or $\Delta \mathrm{P}_{\mathrm{ET}} \mathrm{CO}_{2}$.

227

\section{Discussion}

229 Aerobic exercise, identical to the intensity used in this study, is recommended for overall health

230 post-stroke. ${ }^{11}$ This study provides novel and relevant information regarding cerebrovascular

231 response to moderate intensity exercise for individuals at 3- and 6-months post-stroke. The main

232 primary findings of the current investigation are: 1) MCAv kinetic response was stable from 3 to

2336 months post-stroke for bilateral MCA and 2) MCAv kinetic response (amplitude and TD)

234 significantly differed for those with higher estimated $V \square \mathrm{O}_{2}$ maximum. This finding was

235 consistent for the stroke affected MCA at 3- and 6-months.

MCAv Dynamic Response Across Time

238 The primary objective of this study was to characterize the MCAv response at 3- and 6- months

239 post-stroke. To our knowledge, this longitudinal cerebrovascular assessment at rest and in

240 response to exercise had not been previously conducted. We hypothesized that the MCAv

241 dynamic response profile would improve from 3 to 6 months post-stroke. This rationale was

242 developed from published work highlighting improved longitudinal changes in aerobic fitness at

2431,3 and 6 months post-stroke ${ }^{12}$ and aerobic fitness positively influences peripheral vascular

244 health measures in individuals post-stroke. ${ }^{13}$ Our hypothesis that MCAv dynamic response

245 would improve with time was not supported by our findings. We have reported high

246 reproducibility within older adults for resting and exercise $\mathrm{MCAv}^{14}$ and bilateral reproducibility 
medRxiv preprint doi: https://doi.org/10.1101/2020.05.13.20100883; this version posted May 16, 2020. The copyright holder for this preprint (which was not certified by peer review) is the author/funder, who has granted medRxiv a license to display the preprint in perpetuity.

It is made available under a CC-BY-NC 4.0 International license.

247 for the MCAv kinetic measures. ${ }^{6}$ Therefore, measurement error from our sonographers (SP, CK)

248 was unlikely.

MCAv Dynamic and Hemodynamic Responses 3 Months Post-Stroke

251 During exercise onset, neural activation increases the metabolic requirements of the brain above

252 resting values in order to maintain normal function ${ }^{15-18}$ and this demand is met with increased

253 cerebral blood flow. Our laboratory ${ }^{6,19}$ and others ${ }^{17,18,20}$ have shown that moderate intensity

254 continuous exercise produces the greatest increase in MCAv compared to low and high intensity

255 (above anaerobic threshold) continuous exercise.

257 Ten of the twenty-one individuals enrolled demonstrated a non-exponential MCAv response

258 (non-responders) following exercise onset. This could be indicative of slowed vasomotor control

259 within the cerebrovasculature as both sides showed slower MCAv kinetics or non-exponential

260 MCAv increase. ${ }^{4}$ When considering potential factors, the data in Table 3 show no between group

261 differences for age, sex, race or ethnicity, time of study visit, or the calculated lesion size (SXB)

262 from the electronic medical record. ${ }^{21,22}$ We found responders had greater statin use, self-reported

263 physical activity levels and estimated $V \square \mathrm{O}_{2}$ maximum values. One previous study grouped

264 healthy young adults based on self-reported physical activity levels into low and high fitness. ${ }^{23}$

265 Those in the high fitness group demonstrated a greater change in MCAv in response to

266 rebreathing-induced hypercapnia while no resting MCAv differences were found. This finding,

267 combined with the present study, underscores the value in considering dynamic challenges such

268 as exercise. Further, others have reported that physically active individuals with higher $V \square \mathrm{O}_{2}$

269 maximum values exhibit better cerebral hemodynamics than sedentary individuals. ${ }^{24,25}$ Although 
medRxiv preprint doi: https://doi.org/10.1101/2020.05.13.20100883; this version posted May 16, 2020. The copyright holder for this preprint (which was not certified by peer review) is the author/funder, who has granted medRxiv a license to display the preprint in perpetuity.

It is made available under a CC-BY-NC 4.0 International license .

270 the evidence reporting the dynamic cerebrovascular response to exercise in stroke is

271 limited, ${ }^{1,2,6,10}$ the present study suggests that physical activity and exercise post-stroke may

272 confer some benefit to overall cerebrovascular health. We acknowledge individuals in the

273 responder group also reported a significantly higher use of statin medications. One study showed

2743 months of statin treatment after stroke improved cerebrovascular reactivity compared to the

275 control group while no differences in resting cerebral blood flow were reported. ${ }^{26}$ Our planned

276 future work aims to test whether aerobic exercise interventions can increase the MCAv kinetic

277 response profile and other cerebrovascular outcomes after stroke.

278

279 The BL values and steady state hemodynamic responses during the exercise bout were not

280 significantly different between groups. We report between group differences for $\triangle \mathrm{MAP}$ and

$281 \Delta \mathrm{HR}$. We acknowledge that these differences may be largely driven by the significantly higher

282 workload in the responder group, which likely influenced the MCAv amplitude response. One

283 individual (responder) who exercised at 110 watts largely influenced the difference in work rate.

284 He was an avid cyclist prior to his stroke and interestingly, had the largest stroke lesion at

285 admission to the hospital. We report no between group differences for BL, steady state or

$286 \Delta \mathrm{P}_{\mathrm{ET}} \mathrm{CO}_{2}$. We are confident that the lower MCAv amplitude in the non-responders is not the

287 result of hyperventilation. We closely monitor $\mathrm{P}_{\mathrm{ET}} \mathrm{CO}_{2}$ during the exercise bout to ensure our

288 participants stay within the prescribed HR range without hyperventilation. ${ }^{6}$

290 The literature is well-established that MAP increases with age ${ }^{27}$ and after stroke, ${ }^{11}$ which

291 provides unique opportunities to study exercise-induced changes in MAP and HR. The

292 cerebrovasculature and the associated neuroprotective mechanisms have the ability to 
medRxiv preprint doi: https://doi.org/10.1101/2020.05.13.20100883; this version posted May 16, 2020. The copyright holder for this preprint (which was not certified by peer review) is the author/funder, who has granted medRxiv a license to display the preprint in perpetuity.

It is made available under a CC-BY-NC 4.0 International license .

autoregulate and buffer the sudden acute increases in MAP associated across various exercise intensities. ${ }^{28}$ As observed in Figure 1, the non-responders show a rapid rise in the MCAv response to exercise followed by an immediate decline with steady state values near BL. One proposed hypothesis for this unexpected response may be an impairment in the cerebrovascular control mechanisms following stroke. ${ }^{6}$ Despite the increased neural activation with exercise and demand for energy, MCAv did not increase. Another plausible explanation may be an impairment in the feed-forward signals coming from the motor cortex to increase MCAv concomitantly with neuromuscular innervation. ${ }^{4,29}$ Our data extend current knowledge regarding cerebrovascular response to exercise and is timely given the increased interest and concern for the role of high-intensity interval training on cerebrovascular response, especially for those with neurological conditions such as stroke..$^{28,30,31}$ The authors of these review papers ${ }^{28,31}$ and a recent study describing the cerebrovascular response to a 30-second bout of high intensity exercise ${ }^{30}$ suggest that caution should be taken when implementing this type of protocol, as the evidence for safety with respect to the brain and its delicate cerebrovasculature has not been tested. A recently published clinical practice guideline for physical therapy suggests higher locomotor intensities benefit walking speed and endurance in chronic stroke. ${ }^{32}$ The current knowledge of cerebrovascular control during an acute exercise bout, especially following stroke, is still in its infancy and warrants further investigation.

\section{MCAv Dynamic and Hemodynamic Responses 6 Months Post-Stroke}

In the chronic phase of stroke recovery, the responders continued to exercise at higher

workloads, which may have influenced cerebrovascular response during the exercise bout. At

this study visit, only differences in TD and amplitude on the stroke affected vessel remained. All 
medRxiv preprint doi: https://doi.org/10.1101/2020.05.13.20100883; this version posted May 16, 2020. The copyright holder for this preprint (which was not certified by peer review) is the author/funder, who has granted medRxiv a license to display the preprint in perpetuity.

It is made available under a CC-BY-NC 4.0 International license .

other MCAv kinetic variables and hemodynamic responses were not significant. The reduced sample size warrants caution when interpreting the findings. A noteworthy observation is two of the three newly characterized responders had increased their self-reported physical activity.

319 Whether the increase in physical activity was the primary driver of the higher MCAv amplitude responses remains an important query for future work.

322 Several limitations in the study design should be considered. First, as with all studies using

323 transcranial Doppler ultrasound, the assumption of constant MCA diameter is important in order

324 for the $\mathrm{MCA}_{\mathrm{V}}$ to be used as a direct proxy for cerebral blood flow. ${ }^{6}$ Second, maximal exercise

325 testing was not performed to determine maximal heart rate to more accurately prescribe the

326 moderate intensity exercise session. However, as evidenced by the increase in $\mathrm{P}_{\mathrm{ET}} \mathrm{CO}_{2}$ during

327 exercise, it is unlikely that individuals exercised above anaerobic levels. Third, we observed an

328 increase in BL MCAv prior to exercise onset. This could be an anticipatory response or

329 nervousness to our verbal instructions 15 seconds prior to exercise onset.

\section{Conclusion}

332 The cerebrovascular response to acute exercise remained stable between 3- and 6-months post-

333 stroke. Physical activity participation may positively influence the MCAv dynamic response

334 during exercise. Further exploration into the cerebrovascular control mechanisms or other stroke-

335 specific characteristics that may result in a diminished response (non-responders) to exercise and

336 various intensities is needed. The MCAv kinetic response may better inform future exercise trials

337 designed to benefit overall brain health. 
medRxiv preprint doi: https://doi.org/10.1101/2020.05.13.20100883; this version posted May 16, 2020. The copyright holder for this preprint (which was not certified by peer review) is the author/funder, who has granted medRxiv a license to display the preprint in perpetuity.

It is made available under a CC-BY-NC 4.0 International license .

\section{Acknowledgments}

We would like to thank Yumei Liu, MD, PhD and Emily Nardo for their assistance with data collection and Madison Henry, SPT for her assistance with data organization.

\section{Sources of funding}

344 Dr. Billinger was supported by the Eunice Kennedy Shriver National Institute of Child Health and Human Development (K01HD067318) and the Wohlgemuth Faculty Scholar Award. Dr. Whitaker and Ms. Morton were supported in part by T32HD057850 from the Eunice Kennedy

347 Shriver National Institute of Child Health and Human Development. Ms. Morton received 348 support from aStudent Scholarship in Cerebrovascular Disease and Stroke (American Heart 349 Association). Dr. Perdomo received partial support from the University of Kansas Alzheimer's

350 Disease Center (P30AG035982), the KU Medical Center Biomedical Research Training Program 351 and from the National Institute on Aging Diversity Supplement to R01 AG058162. REDCap at

352 University of Kansas Medical Center is supported by CTSA Award (UL1TR000001) from 353 NCRR and NCATS. This work was supported from NCATS awarded to the University of 354 Kansas for Frontiers: Clinical and Translational Science Institute (UL1TR002366) The contents 355 are solely the responsibility of the authors and do not necessarily represent the official views of 356 the NIH or NCATS.

\section{Disclosures}

359 SAB reports a patent pending (18KU028M-02). MA reports consulting for Stryker

360 Neurovascular and Penumbra Inc. outside the submitted work. AW, AM, CK, SP, JW, SE, SB, 361 and LL report no conflicts of interest. 
medRxiv preprint doi: https://doi.org/10.1101/2020.05.13.20100883; this version posted May 16, 2020. The copyright holder for this preprint (which was not certified by peer review) is the author/funder, who has granted medRxiv a license to display the preprint in perpetuity.

It is made available under a CC-BY-NC 4.0 International license .

\section{References}

1. Robertson AD, Atwi S, Kostoglou K, et al. Cerebrovascular Pulsatility During Rest and Exercise Reflects Hemodynamic Impairment in Stroke and Cerebral Small Vessel Disease. Ultrasound in medicine \& biology. 2019;45(12):3116-3127.

2. Kempf KS, Whitaker AA, Lui Y, et al. The Effect of Stroke on Middle Cerebral Artery Blood Flow Velocity Dynamics During Exercise. J Neurol Phys Ther. 2019;43(4):212219.

3. Ivey FM, Ryan AS, Hafer-Macko CE, Macko RF. Improved cerebral vasomotor reactivity after exercise training in hemiparetic stroke survivors. Stroke. 2011;42(7):1994-2000.

4. Ward JL, Craig JC, Liu Y, et al. Effect of Healthy Aging and Sex on Middle Cerebral Artery Blood Velocity Dynamics During Moderate Intensity Exercise. American journal of physiology Heart and circulatory physiology. 2018.

5. Guo ZN, Liu J, Xing Y, et al. Dynamic cerebral autoregulation is heterogeneous in different subtypes of acute ischemic stroke. PLoS One. 2014;9(3):e93213.

6. Billinger SA, Craig JC, Kwapiszeski SJ, Sisante J-FV, Vidoni ED, Maletsky R. Dynamics of middle cerebral artery blood flow velocity during moderate intensity exercise. In. Journal of Applied Physiology2017.

7. Brawner CA, Ehrman JK, Schairer JR, Cao JJ, Keteyian SJ. Predicting maximum heart rate among patients with coronary heart disease receiving beta-adrenergic blockade therapy. Am Heart J. 2004;148(5):910-914.

8. A language and environment for statistical computing. [computer program]. Vienna, Austria: R Foundation for Statistical Computing; 2013. 
medRxiv preprint doi: https://doi.org/10.1101/2020.05.13.20100883; this version posted May 16, 2020. The copyright holder for this preprint (which was not certified by peer review) is the author/funder, who has granted medRxiv a license to display the preprint in perpetuity.

It is made available under a CC-BY-NC 4.0 International license .

9. Crapo RO, Casaburi R, Coates AL, et al. ATS Statement: Guidelines for Six-Minute Walk Test. American Journal of Respiratory and Critical Care Medicine. 2002;166:111 117.

10. Kaufman CS, Bai SX, Ward JL, Eickmeyer SM, Billinger SA. Middle cerebral artery velocity dynamic response profile during exercise is attenuated following multiple ischemic strokes: a case report. Physiol Rep. 2019;7(21):e14268.

11. Billinger SA, Arena R, Bernhardt J, et al. Physical Activity and Exercise Recommendations for Stroke Survivors: A Statement for Healthcare Professionals From the American Heart Association/American Stroke Association. Stroke. 2014;45(8):25322553.

12. Mackay-Lyons MJ, Makrides L. Longitudinal changes in exercise capacity after stroke. Arch Phys Med Rehabil. 2004;85(10):1608-1612.

13. Billinger SA, Mattlage AE, Ashenden AL, Lentz AA, Harter G, Rippee MA. Aerobic exercise in subacute stroke improves cardiovascular health and physical performance. $J$ Neurol Phys Ther. 2012;36(4):159-165.

14. Perdomo SJ, Ward J, Liu Y, et al. Cardiovascular Disease Risk Is Associated With Middle Cerebral Artery Blood Flow Velocity in Older Adults. Cardiopulmonary Physical Therapy Journal. 2020;31(2):38-46.

15. Gonzalez-Alonso J, Dalsgaard MK, Osada T, et al. Brain and central haemodynamics and oxygenation during maximal exercise in humans. $J$ Physiol. 2004;557(Pt 1):331-342.

16. Jorgensen LG, Perko M, Hanel B, Schroeder TV, Secher NH. Middle cerebral artery flow velocity and blood flow during exercise and muscle ischemia in humans. Journal of applied physiology. 1992;72(3):1123-1132. 
medRxiv preprint doi: https://doi.org/10.1101/2020.05.13.20100883; this version posted May 16, 2020. The copyright holder for this preprint (which was not certified by peer review) is the author/funder, who has granted medRxiv a license to display the preprint in perpetuity.

It is made available under a CC-BY-NC 4.0 International license .

17. Linkis P, Jorgensen LG, Olesen HL, Madsen PL, Lassen NA, Secher NH. Dynamic exercise enhances regional cerebral artery mean flow velocity. Journal of applied physiology. 1995;78(1):12-16.

18. Moraine JJ, Lamotte M, Berre J, Niset G, Leduc A, Naeije R. Relationship of middle cerebral artery blood flow velocity to intensity during dynamic exercise in normal subjects. European journal of applied physiology and occupational physiology. 1993;67(1):35-38.

19. Witte E, Liu Y, Ward JL, et al. Exercise intensity and middle cerebral artery dynamics in humans. Respir Physiol Neurobiol. 2019;262:32-39.

20. Ide K, Horn A, Secher NH. Cerebral metabolic response to submaximal exercise. Journal of applied physiology. 1999;87(5):1604-1608.

21. Newman GC. Clarification of abc/2 rule for ICH volume. Stroke. 2007;38(3):862.

22. Majersik JJ, Cole JW, Golledge J, et al. Recommendations from the international stroke genetics consortium, part 1: standardized phenotypic data collection. Stroke. 2015;46(1):279-284.

23. Hwang J, Kim K, Brothers RM, Castelli DM, Gonzalez-Lima F. Association between aerobic fitness and cerebrovascular function with neurocognitive functions in healthy, young adults. Exp Brain Res. 2018;236(5):1421-1430.

24. Ainslie PN, Cotter JD, George KP, et al. Elevation in cerebral blood flow velocity with aerobic fitness throughout healthy human ageing. J Physiol. 2008;586(16):4005-4010.

25. Bailey DM, Marley CJ, Brugniaux JV, et al. Elevated aerobic fitness sustained throughout the adult lifespan is associated with improved cerebral hemodynamics. Stroke. 2013;44(11):3235-3238. 
medRxiv preprint doi: https://doi.org/10.1101/2020.05.13.20100883; this version posted May 16, 2020. The copyright holder for this preprint (which was not certified by peer review) is the author/funder, who has granted medRxiv a license to display the preprint in perpetuity.

It is made available under a CC-BY-NC 4.0 International license .

431 26. Pretnar-Oblak J, Sabovic M, Sebestjen M, Pogacnik T, Zaletel M. Influence of

432

433

434

435

436

437

438

439

440

441

442

443

444

445

446

447

448

449

450

451

atorvastatin treatment on L-arginine cerebrovascular reactivity and flow-mediated

dilatation in patients with lacunar infarctions. Stroke. 2006;37(10):2540-2545.

27. Hart EC, Joyner MJ, Wallin BG, Charkoudian N. Sex, ageing and resting blood pressure: gaining insights from the integrated balance of neural and haemodynamic factors. $J$ Physiol. 2012;590(9):2069-2079.

28. Lucas SJ, Cotter JD, Brassard P, Bailey DM. High-intensity interval exercise and cerebrovascular health: curiosity, cause, and consequence. J Cereb Blood Flow Metab. 2015;35(6):902-911.

29. Sato K, Sadamoto T, Ueda-Sasahara C, et al. Central command and the increase in middle cerebral artery blood flow velocity during static arm exercise in women. Experimental physiology. 2009;94(11):1132-1138.

30. Labrecque L, Drapeau A, Rahimaly K, Imhoff S, Billaut F, Brassard P. Comparable blood velocity changes in middle and posterior cerebral arteries during and following acute high-intensity exercise in young fit women. Physiol Rep. 2020;8(9):e14430.

31. Calverley TA, Ogoh S, Marley CJ, et al. HIITing the brain with exercise; mechanisms, consequences and practical recommendations. J Physiol. 2020.

32. Hornby TG, Reisman DS, Ward IG, et al. Clinical Practice Guideline to Improve Locomotor Function Following Chronic Stroke, Incomplete Spinal Cord Injury, and Brain Injury. J Neurol Phys Ther. 2020;44(1):49-100. 
Table 1. Participant Demographics $(n=26)$

\begin{tabular}{|c|c|}
\hline Age (years) & $63.0 \pm 14.0$ \\
\hline \multicolumn{2}{|l|}{$\operatorname{Sex} \%(\mathrm{n})$} \\
\hline Female & $31 \%(8)$ \\
\hline Male & $69 \%(18)$ \\
\hline \multicolumn{2}{|l|}{ Race/Ethnicity* (n) } \\
\hline White & 18 \\
\hline Black & 8 \\
\hline Native American & 1 \\
\hline Hispanic/Latino & 0 \\
\hline Asian & 1 \\
\hline Pacific Islander & 0 \\
\hline $\mathrm{tPA}(\mathrm{n})$ & 14 \\
\hline Thrombectomy (n) & 9 \\
\hline tPA and Thrombectomy (n) & 3 \\
\hline Resting SBP (mm Hg) & $138.5 \pm 18.3$ \\
\hline Resting DBP (mm Hg) & $80.4 \pm 11.2$ \\
\hline $\mathrm{BMI}\left(\mathrm{kg} *\left(\mathrm{~m}^{2}\right)^{-1}\right)$ & $29.8 \pm 5.5$ \\
\hline Time Post Stroke to 3-month visit (days) & $96.3 \pm 12.6$ \\
\hline Lesion Size $\left(\mathrm{cm}^{3}\right)$ & $40.2 \pm 76.5$ \\
\hline Estimated $V \square \mathrm{O}_{2}$ maximum $\left(\mathrm{ml}^{*} \mathrm{~kg}^{-1} * \min ^{-1}\right)$ & $23.2 \pm 8.9$ \\
\hline \multicolumn{2}{|l|}{ Medications (n) } \\
\hline Beta Blocker & 17 \\
\hline Calcium Channel Blocker & 7 \\
\hline ACE Inhibitor & 5 \\
\hline Angiotensin II Receptor Blocker & 5 \\
\hline Statins & 19 \\
\hline Diuretics & 3 \\
\hline Blood Thinners & 12 \\
\hline Aspirin & 12 \\
\hline Metformin & 5 \\
\hline Insulin & 6 \\
\hline Antidepressants & 9 \\
\hline \multicolumn{2}{|c|}{$\begin{array}{l}\text { Data are presented as Mean } \pm \text { SD unless stated otherwise. *Multiple race categories } \\
\text { selected. tPA = Tissue Plasminogen Activator; SBP = Resting Systolic Blood Pressure; } \\
\text { DBP = Resting Diastolic Blood Pressure; BMI = Body Mass Index; } V \square \mathrm{O}_{2}=\text { oxygen uptake; } \\
\text { ACE = Angiotensin Converting Enzyme. }\end{array}$} \\
\hline
\end{tabular}


Table 2. Kinetic Response Across Time

\begin{tabular}{cccccc}
3 months & 3 months & 6 months & 6 months & F-test & P-value \\
$(\mathrm{n}=22)$ & $95 \mathrm{CI}$ & $(\mathrm{n}=15)$ & $95 \mathrm{CI}$ & & \\
\hline
\end{tabular}

\section{Stroke Affected MCAv}

\begin{tabular}{|c|c|c|c|c|c|c|}
\hline $\mathrm{BL}\left(\mathrm{cm}^{*} \mathrm{~s}^{-1}\right)$ & $51.1 \pm 16.3$ & $43.9-58.4$ & $50.2 \pm 12.5$ & $43.3-57.1$ & 1.9 & 0.19 \\
\hline $\mathrm{TD}(\mathrm{s})$ & $55.6 \pm 57.4$ & $26.1-85.1$ & $59.0 \pm 52.6$ & $25.5-92.4$ & 0.2 & 0.70 \\
\hline $\operatorname{Amp}\left(\mathrm{cm}^{*} \mathrm{~s}^{-1}\right)$ & $5.5 \pm 5.8$ & $2.6-8.3$ & $5.8 \pm 5.2$ & $2.5-9.0$ & 0.3 & 0.63 \\
\hline$\tau(\mathrm{s})$ & $34.6 \pm 34.6$ & $16.8-52.4$ & $53.9 \pm 53.9$ & $19.6-88.1$ & 1.6 & 0.24 \\
\hline
\end{tabular}

Non-Stroke Affected MCAv

$\begin{array}{lcccccc}\mathrm{BL}\left(\mathrm{cm}^{*} \mathrm{~s}^{-1}\right) & 62.1 \pm 23.7 & 50.7-73.6 & 56.2 \pm 12.8 & 48.8-63.6 & 1.3 & 0.27 \\ \mathrm{TD}(\mathrm{s}) & 42.2 \pm 38.6 & 17.7-66.7 & 62.7 \pm 38.8 & 38.0-87.4 & 3.0 & 0.11 \\ \mathrm{Amp}\left(\mathrm{cm}^{*} \mathrm{~s}^{-1}\right) & 7.2 \pm 5.8 & 3.5-10.90 & 7.3 \pm 4.7 & 4.3-10.30 & 0.4 & 0.56 \\ \tau(\mathrm{s}) & 25.4 \pm 19.1 & 13.3-37.5 & 21.0 \pm 27.3 & 3.6-38.3 & 0.0 & 0.91\end{array}$

Data are presented as Mean \pm SD. $\mathrm{CI}=$ Confidence Interval; $\mathrm{BL}=$ Baseline MCAv; $\mathrm{TD}=$ Time Delay; Amp $=$ Amplitude; $\tau=$ Time Constant 
Table 3. Characteristics of Responders and Non-Responders

\begin{tabular}{|c|c|c|c|c|c|c|}
\hline & $\begin{array}{l}\text { Responders } \\
\quad(n=12)\end{array}$ & $\begin{array}{l}\text { Responders } \\
95 \mathrm{CI}\end{array}$ & $\begin{array}{c}\text { Non- } \\
\text { Responders } \\
(n=10)\end{array}$ & $\begin{array}{c}\text { Non- } \\
\text { Responders } 95 \\
\text { CI }\end{array}$ & F-test & P-value \\
\hline Age (years) & $59.4 \pm 12.5$ & $51.5-67.4$ & $67.3 \pm 16.1$ & $55.8-78.8$ & 1.7 & 0.21 \\
\hline \multicolumn{7}{|l|}{ Sex $\%(n)$} \\
\hline Female & $63 \%(5)$ & & $37 \%(3)$ & & & \\
\hline Male & $50 \%(7)$ & & $50 \%(7)$ & & & 0.68 \\
\hline \multicolumn{7}{|l|}{ Race/Ethnicity* (n) } \\
\hline White & 10 & & 5 & & & 0.17 \\
\hline Black & 2 & & 5 & & & 0.17 \\
\hline Native American & 0 & & 1 & & & 0.46 \\
\hline Hispanic/Latino & 0 & & 0 & & & \\
\hline Asian & 0 & & 1 & & & 0.46 \\
\hline Pacific Islander & 0 & & 0 & & & \\
\hline Time Post Stroke to 3-month visit (days) & $94.8 \pm 8.3$ & $89.5-100.0$ & $99.5 \pm 18.0$ & $86.6-112.4$ & 0.7 & 0.42 \\
\hline BMI $\left(\mathrm{kg}^{*}\left(\mathrm{~m}^{2}\right)^{-1}\right)$ & $31.2 \pm 6.2$ & $27.3-35.2$ & $28.2 \pm 4.9$ & $24.7-31.8$ & 1.5 & 0.24 \\
\hline Lesion Size $\left(\mathrm{cm}^{3}\right)$ & $70.6 \pm 97.4$ & $-4.2-145.5$ & $20.7 \pm 52.5$ & $-23.2-64.5$ & 1.7 & 0.22 \\
\hline $\begin{array}{l}\text { Estimated } V \square \mathrm{O}_{2} \text { maximum (ml* } \mathrm{kg}^{-1} * \min ^{-} \\
{ }^{1} \text { ) }\end{array}$ & $26.6 \pm 8.9$ & $20.9-32.3$ & $18.3 \pm 8.0$ & $12.6-24.0$ & 5.2 & 0.03 \\
\hline Physical Activity Score & $2.8 \pm 1.3$ & $1.9-3.6$ & $1.6 \pm 0.7$ & $1.1-2.1$ & 6.4 & 0.02 \\
\hline MoCA & $22.0 \pm 5.8$ & $18.3-25.7$ & $23.8 \pm 3.3$ & $21.4-26.2$ & 0.8 & 0.39 \\
\hline $\mathrm{mRS}$ & $2.1 \pm 0.9$ & $1.5-2.5$ & $2.2 \pm 1.0$ & $1.5-2.9$ & 0.3 & 0.62 \\
\hline 6-minute Walk Test (m) & $338.4 \pm 128.0$ & $257.1-419.8$ & $264.6 \pm 128.9$ & $165.5-363.6$ & 1.7 & 0.21 \\
\hline Thrombectomy (n) & 4 & & 1 & & & 0.32 \\
\hline tPA and Thrombectomy (n) & 2 & & 1 & & & 1.00 \\
\hline tPA (n) & 3 & & 6 & & & 0.19 \\
\hline \multicolumn{7}{|l|}{ Medications (n) } \\
\hline Beta Blocker & 8 & & 7 & & & 1.00 \\
\hline Calcium Channel Blocker & 5 & & 2 & & & 0.38 \\
\hline ACE Inhibitor & 4 & & 0 & & & 0.10 \\
\hline
\end{tabular}


Angiotensin II Receptor Blocker

Statins

Diuretics

Blood Thinners

Aspirin

Insulin

Metformin

Antidepressants
3

11

1

7

4

1

1

4
1.00

0.03

1.00

0.67

0.67

0.14

0.57

1.00

Data are presented as Mean \pm SD unless stated otherwise. $*$ Multiple race categories selected. BMI $=$ Body Mass Index; $V \square \mathrm{O}_{2}=$ oxygen uptake; MoCA = Montreal Cognitive Assessment; $\mathrm{mRS}=$ Modified Rankin Scale; $\mathrm{tPA}=$ Tissue Plasminogen Activator; $\mathrm{ACE}=$ Angiotensin Converting Enzyme. 
Table 4. MCAv Kinetics and Exercise Parameters For Responders and Non-Responders

\begin{tabular}{|c|c|c|c|c|c|c|}
\hline & $\begin{array}{l}\text { Responders } \\
(\mathrm{n}=12)\end{array}$ & $\begin{array}{c}\text { Responders } \\
95 \mathrm{CI} \\
\end{array}$ & $\begin{array}{c}\text { Non-Responders } \\
(\mathrm{n}=10)\end{array}$ & $\begin{array}{c}\text { Non-Responders } \\
95 \mathrm{CI} \\
\end{array}$ & F-test & P-value \\
\hline \multicolumn{7}{|l|}{ Stoke Affected MCAv } \\
\hline $\mathrm{BL}\left(\mathrm{cm}^{*} \sec ^{-1}\right)$ & $54.2 \pm 15.0$ & $44.6-63.7$ & $47.5 \pm 17.7$ & $34.8-60.2$ & 0.9 & 0.35 \\
\hline $\mathrm{TD}(\mathrm{s})$ & $32.9 \pm 40.5$ & $7.1-58.6$ & $110.1 \pm 58.4 \pm$ & $37.6-182.6$ & 10.0 & 0.006 \\
\hline $\operatorname{Amp}\left(\mathrm{cm}^{*} \mathrm{sec}^{-1}\right)$ & $8.2 \pm 4.8$ & $5.1-11.2$ & $0.10 \pm 3.2 \pm$ & $-3.2-3.4$ & 13.7 & 0.002 \\
\hline$\tau(\mathrm{s})$ & $30.2 \pm 24.7$ & $14.5-45.8$ & $45.2 \pm 53.8 \pm$ & $-21.7-112.0$ & 0.7 & 0.43 \\
\hline \multicolumn{7}{|c|}{ Non-Stroke Affected MCAv } \\
\hline $\mathrm{BL}\left(\mathrm{cm}^{*} \mathrm{sec}^{-1}\right)$ & $59.9 \pm 15.0$ & $49.8-69.9$ & $54.4 \pm 13.5$ & $41.9-66.9$ & 0.23 & 0.64 \\
\hline $\mathrm{TD}(\mathrm{s})$ & $36.2 \pm 34.1$ & $13.3-59.1$ & $107.8^{*}$ & - & - & - \\
\hline $\operatorname{Amp}\left(\mathrm{cm}^{*} \mathrm{sec}^{-1}\right)$ & $8.3 \pm 4.4$ & $5.3-11.3$ & $-5.2 *$ & - & - & - \\
\hline$\tau(\mathrm{s})$ & $22.7 \pm 17.5$ & $11.0-34.6$ & $54.6^{*}$ & - & - & - \\
\hline BL MAP (mmHg) & $77.6 \pm 19.1$ & $65.3-89.7$ & $80.6 \pm 19.0$ & $67.0-94.2$ & 0.14 & 0.71 \\
\hline SS MAP (mmHg) & $98.4 \pm 16.8$ & $87.7-109.1$ & $91.2 \pm 25.6$ & $72.9-109.6$ & 0.6 & 0.44 \\
\hline$\triangle \mathrm{MAP}(\mathrm{mmHg})$ & $20.8 \pm 9.6$ & $14.7-26.9$ & $10.6 \pm 12.0$ & $2.0-19.2$ & 7.3 & 0.04 \\
\hline $\mathrm{BL} \mathrm{P}_{\mathrm{ET}} \mathrm{CO}_{2}(\mathrm{mmHg})$ & $34.6 \pm 3.6$ & $32.3-37.0$ & $35.1 \pm 5.1$ & $31.2-39.1$ & 0.1 & 0.81 \\
\hline $\mathrm{SS} \mathrm{P}_{\mathrm{ET}} \mathrm{CO}_{2}(\mathrm{mmHg})$ & $39.3 \pm 4.4$ & $36.5-41.6$ & $38.2 \pm 4.4$ & $34.9-41.6$ & 0.3 & 0.61 \\
\hline$\Delta \mathrm{P}_{\mathrm{ET}} \mathrm{CO}_{2}(\mathrm{mmHg})$ & $4.6 \pm 2.3$ & $3.2-6.1$ & $3.1 \pm 1.8$ & $1.7-4.5$ & 1.6 & 0.13 \\
\hline BL HR (bpm) & $65.4 \pm 8.9$ & $59.8-71.1$ & $69.9 \pm 11.3$ & $61.8-77.9$ & 1.1 & 0.31 \\
\hline SS HR (bpm) & $94.5 \pm 13.1$ & $86.2-102.8$ & $87.6 \pm 18.1$ & $74.6-100.6$ & 1.1 & 0.31 \\
\hline$\Delta \mathrm{HR}(\mathrm{bpm})$ & $29.1 \pm 9.5$ & $23.1-35.1$ & $17.7 \pm 11.9$ & $9.2-26.3$ & 6.2 & 0.02 \\
\hline Workload (watts) & $52.9 \pm 25.4$ & $36.8-69.1$ & $36.0 \pm 12.0$ & $27.4-44.6$ & 3.7 & 0.07 \\
\hline RPE & $12.8 \pm 2.2$ & $11.3-14.2$ & $13.4 \pm 3.1$ & $11.2-15.6$ & 0.3 & 0.58 \\
\hline
\end{tabular}


Data are presented as Mean \pm SD. $\mathrm{CI}=$ Confidence Interval; $\mathrm{BL}=$ Baseline MCAv; TD $=$ Time Delay; Amp $=$ Amplitude; $\tau=$ Time Constant; $\mathrm{BL}=$ Baseline; $\mathrm{SS}=$ Steady-State Exercise; $\mathrm{MAP}=$ Mean Arterial Pressure $; \mathrm{P}_{\mathrm{ET}} \mathrm{CO}_{2}=$ End Tidal Carbon Dioxide; HR= Heart Rate; RPE $=$ Rate of Perceived Exertion. \pm Data represent $n=5$. *Data represents 1 dataset that modeled an exponential response. 
medRxiv preprint doi: https://doi.org/10.1101/2020.05.13.20100883; this version posted May 16, 2020. The copyright holder for this preprint (which was not certified by peer review) is the author/funder, who has granted medRxiv a license to display the preprint in perpetuity.

It is made available under a CC-BY-NC 4.0 International license .

452 Figure 1. Responders versus Non-Responders, Stoke Affected and Non-Stroke Affected MCAv

453 response to moderate intensity exercise

454

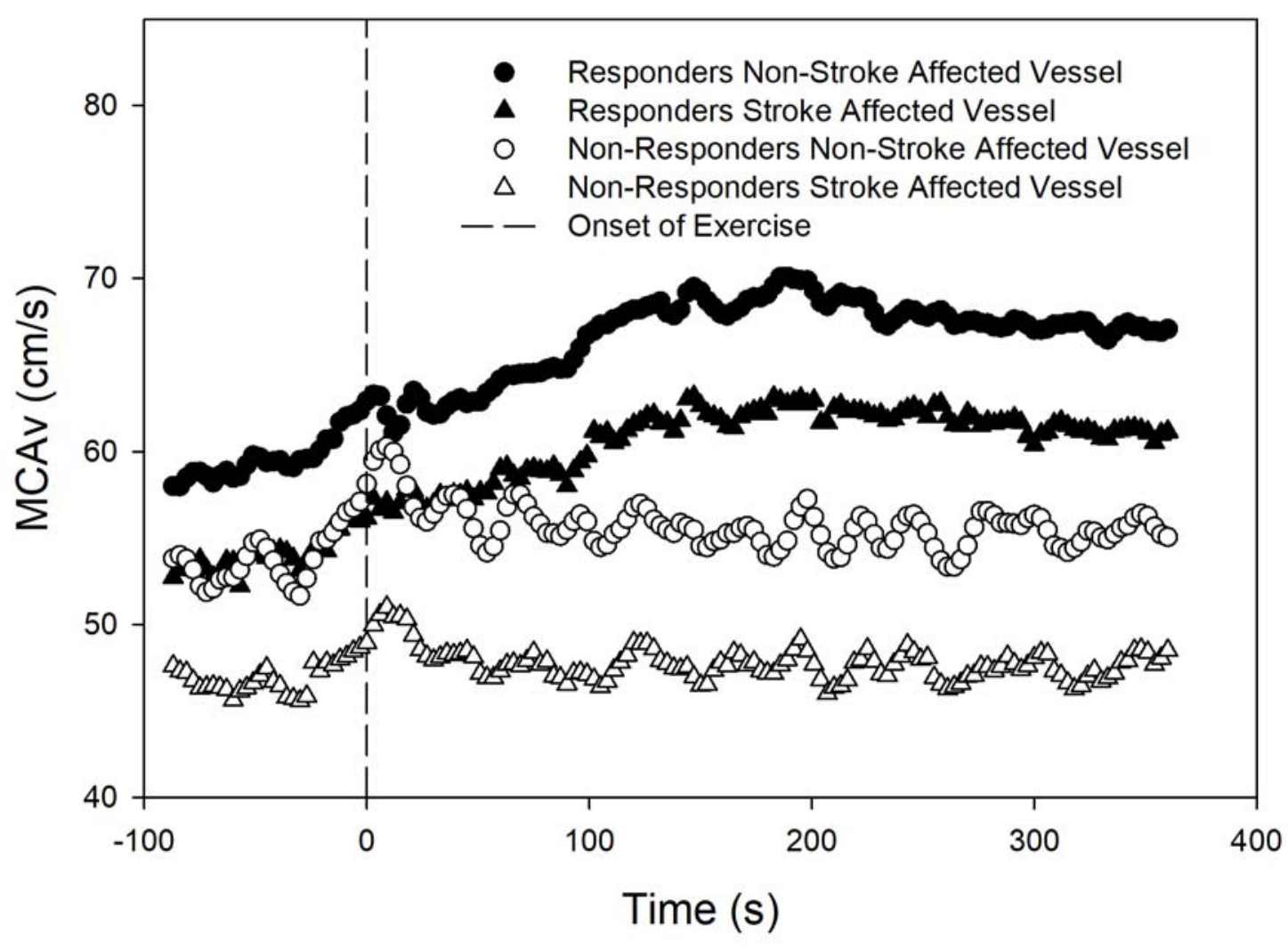

